\title{
An Analysis of Mental Toughness Between Successful and Unsuccessful Athletes in Track and Field
}

\author{
Dr. Jaswinder Singh (Ph.D.) \\ Guru Kashi University, Talwandi Sabo, India
}

\begin{abstract}
The aim of the present study was to compare the Mental Toughness between successful and unsuccessful athletes in Track and Field. A total of 100 track and field athlete's aged ranged from 18 to 25 yrs. was randomly selected during all India Inter-university athletic meet. The participant included 50 successful athletes who have won any medal in all India inter-university throughout their life and 50 unsuccessful athletes who have not won a single medal in any of the competition in all India university level. A questionnaire developed by (PPI; Loehr, 1986) Mental toughness: Psychological Performance Inventory was used to assess the mental toughness of successful and unsuccessful athletes in Track and Field. The obtained data was analyzed by using statistical software (SPSS 17 version). The mean, standard deviation along with t-test has been functional to ensure the difference between samples mean of two group i.e. successful and unsuccessful athletes in track and field at a level of significance 0.05 and after analyzed the obtained data it was found that the mental toughness of successful athletes is comparatively higher than unsuccessful athletes in Track and Field.
\end{abstract}

Key words: $\quad$ Mental Toughness, Successful, Unsuccessful, Track and Field, Athletes

\section{Introduction}

Many coaches are becoming aware of the importance of developing mentally tough performers and are designing programs to develop it in their athletes. One of the most significant problems in designing these programs is the inconsistency in the definition and description of mental toughness. If programs are to be designed with the goal of developing mental toughness in athletes, the components of the construct must be identified. Athletes, coaches, and applied sports psychologists have consistently referred to mental toughness as one of the most important psychological characteristics related to outcomes and success in elite sport, Lee Crust (2007) Creating a tough physical practice environment, a positive mental environment, and providing mental toughness learning opportunities were themes that emerged as strategies coaches used to build mentally tough athletes (Robert Weinberg et al,2011)

\section{Selection of subjects}

For the purpose of the study a total of 100 Track and Field athlete's aged ranged from 18 to $25 \mathrm{yr}$ was randomly selected during all India university athletic meet. The participants included 50 successful $(\mathrm{N}=50)$ athletes who have won any medal at all India university throughout their life and 50 unsuccessful $(\mathrm{N}=50)$ athletes who have not won a single medal in any of the competition at all India university level.

\section{Instrument}

A questionnaire developed by (PPI; Loehr, 1986) Mental toughness: Psychological Performance Inventory consists of 42 items were deliberate to evaluate the factors that replicate mental toughness of successful and unsuccessful athletes in Track and Field.

\section{Administration of the test}

The copies of the Questionnaire were personally distributed with prior permission of all the coaches and team managers to the all the subjects with the request that they shall give correct and accurate answers. Proper instructions regarding the objectives of study and procedure for filling in the Questionnaire were given.

The obtained data was analyzed by using statistical software (SPSS 17 version). The mean, standard deviation along with $\mathrm{t}$ test has been functional to ensure the difference between samples mean of two group i.e. successful and unsuccessful athletes in track and field at a level of significance 0.05 . 


\section{Results}

Table 1: Descriptive statistics of successful and unsuccessful athletes in Track and Field

\begin{tabular}{|c|c|c|c|c|}
\hline Group & N & Mean & Std. Deviation & Std. Error Mean \\
\hline successful athletes & 50 & 19.2724 & 1.08421 & .15333 \\
\hline unsuccessful athlete & 50 & 17.7524 & .81113 & .11471 \\
\hline
\end{tabular}

Table 1 reveals that the means of the successful athletes (19.2724) in Mental Toughness is comparatively higher the means of unsuccessful athletes (17.7524) in Track and Field.

Table 2: t-table for testing the equality of means of successful and unsuccessful athletes in Track and Field

\begin{tabular}{|c|c|c|c|c|c|c|c|c|c|}
\hline & \multicolumn{7}{|c|}{ t-test for Equality of Means } \\
\hline & $\begin{array}{c}\text { Levene's } \\
\text { Test for } \\
\text { Equality of } \\
\text { Variances }\end{array}$ & \multicolumn{7}{|c|}{} & \multicolumn{2}{|c|}{$\begin{array}{c}95 \% \text { Confidence } \\
\text { Interval of the } \\
\text { Difference }\end{array}$} \\
\hline & $\mathrm{F}$ & Sig. & $\mathrm{T}$ & $\mathrm{Df}$ & $\begin{array}{c}\text { Sig. } \\
(2- \\
\text { tailed) }\end{array}$ & $\begin{array}{c}\text { Mean } \\
\text { Difference }\end{array}$ & $\begin{array}{c}\text { Std. Error } \\
\text { Difference }\end{array}$ & Lower & Upper \\
\hline $\begin{array}{c}\text { Equal } \\
\text { variances } \\
\text { assumed }\end{array}$ & 1.046 & .309 & 7.938 & 98 & .000 & 1.52000 & .19149 & 1.13999 & 1.90001 \\
\hline $\begin{array}{c}\text { Equal } \\
\text { variances } \\
\text { not } \\
\text { assumed }\end{array}$ & & & 7.938 & 90.767 & .000 & 1.52000 & .19149 & 1.13961 & 1.90039 \\
\hline
\end{tabular}

Table 2 reveals that the value of $t$-statistics is 7.938 . The $t$-value is significant as the p-value is .000 which is less than 0.05 so the null hypothesis of equality of means of successful and unsuccessful athletes in Track and Field is rejected and it may be concluded that there is a difference in the Mental Toughness of successful and unsuccessful athletes in Track and Field.

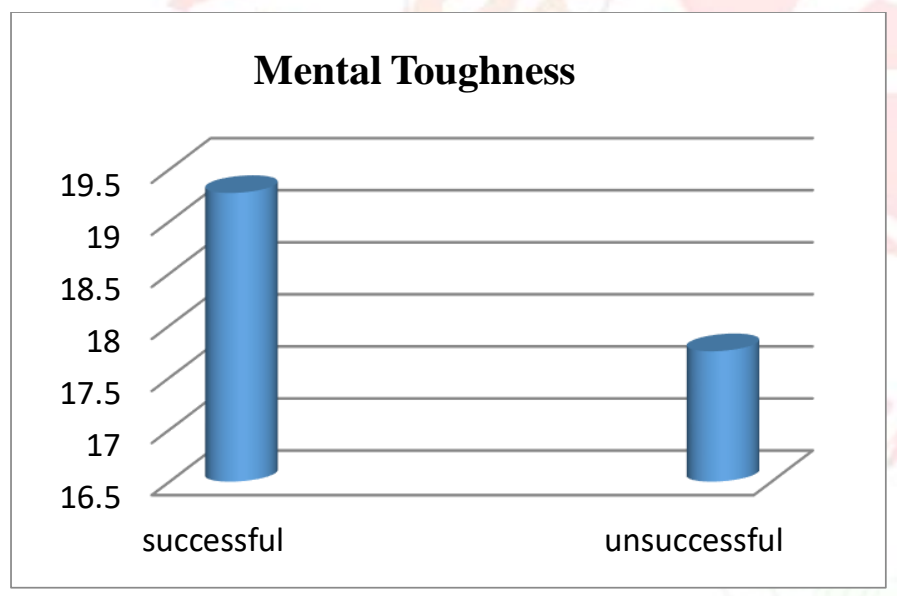

Figure 1: Graphical representation of Mental Toughness of successful and unsuccessful athletes in Track and Field

\section{Discussion of finding}

The purpose of the study was to compare the mental toughness of successful and unsuccessful in Track and Field and after analyzed the obtained data it was found that the mental toughness of successful athletes is comparatively higher than unsuccessful athletes in Track and Field because Physical Talent and Game skill is not enough to perform at mega events, performance is also depend upon mental preparation and psychological strength so mental preparation must be done along with physical preparation for the competitions competition.

Until 1954, most people believed that a human being was incapable of running a mile in less than four minutes. But that very year, English miler Roger Bannister proved them wrong. "Doctors and scientists said that breaking the four-minute mile was impossible, that one would die in the attempt," Bannister is reported to have said afterward. "Thus, when I got up from the track after collapsing at the finish line, I figured I was dead." This goes to show that in sports, as in business, the main obstacle to achieving "the impossible" may be a self-limiting mind-set or mental toughness. As a sports psychologist, it is important to have to spend much of time as a consultant to world class athletes.

Mental toughness of successful athletes may also be comparatively higher than the unsuccessful athletes because the ability to exhaust the pressure is better at the time of competition in the successful athletes, the fighting spirit may also be a factor to enhance the mental toughness of the successful athletes in comparison to the unsuccessful athletes in Track and field. Mental toughness - a term commonly used by coaches, sport psychologists sport commentators, and business leaders - generally describes a collection of attributes that allow a person to persevere through difficult circumstances (such as difficult training or difficult competitive situations in games) and emerge without losing confidence. So the mental toughness of the successful athletes is found to be higher than unsuccessful athletes in track and Field.

\section{References}

[1]. Lee Crust, "Mental toughness in sport: A review; International Journal of Sport and Exercise Psychology, Volume 5, Issue 3,2007

[2]. Robert Weinberga, Joanne Buttb \& Briana Culpa Coaches, views of mental toughness and how it is built, International Journal of Sport and Exercise Psychology, Volume 9, Issue 2,p156-172, 2011

[3]. (Creasy, Jr., John Wayne,2005), An Analysis of the Components of Mental Toughness in Sport, 
Dissertation department of Teaching and Learning, 2005 p 01

[4]. Jones, G., Hanton, S. \& Connaughton, D. (2002). What is this thing called mental toughness? An investigation of elite sport performers. Journal of Applied Sport Psychology, 14, 205-18.

[5]. Loehr, J. E. (1982). Athletic excellence: Mental toughness training for sports. Denver, CO: Forum. Publishing Company.

[6]. Loehr, J. E. (1983). The ideal performance state. Science Periodical on Research and Technology in Sport. Ottawa: Coaching Association of Canada.

[7]. Loehr, J. E. (1986). Mental toughness training for sports: Achieving athletic excellence. Lexington, MA: Stephen Greene Press.

[8]. Meyers, M.C., Bourgeois, A.E., LeUnes, A. and Murray, N.G. (1998) Mood and psychological skills of elite and subelite equestrian athletes. Journal of Sport Behavior 22, 399-409

[9]. Middleton, S.C., Marsh, H.M., Martin, A.J., Richards, G.E. and Perry, C. (2005) Discovering mental toughness: A qualitative study of mental toughness in elite athletes. Psychology Today 22, 60-72.

[10]. Orlick, T., \& Partington, J. (1998). Mental links to excellence. The Sports Psychologist, 2, 105-130. 